\title{
Innovative application technology for challenging inducers of disease resistance in spring rape in (nano) chips
}

\author{
V. Karpachev ${ }^{1}$, N. Voropaeva ${ }^{1}$, A. Tkachev ${ }^{3}$, V. Muhin ${ }^{4}$, V. Varlamov ${ }^{5, *}$, \\ O. Figovsky ${ }^{2}$ \\ ${ }^{1}$ State Research Institute All-Russian Rapeseed Research Institute (ARRI), Lipetsk, Russia \\ ${ }^{2}$ Polymate Ltd.-INRC, Migdal Ha Emek, Israel \\ ${ }^{3}$ Tambov State Technical University, Tambov, Russia \\ ${ }^{4}$ «ENPO "NEORGANIKA“, Joint Stock Company, Moscow Region, Russia \\ ${ }^{5}$ Centre «Bioengineering» RAS, Lipetsk c., Boyevoyproezd, 26, Moscow, 398037, Russia \\ *Tel.IFax.: (4742) 34-63-61 \\ *E-mail address: bionanotex_|@mail.ru
}

Dedicated to the blessed memory of

Prof. Ruban Igor Nikolaevich

\begin{abstract}
The present level of development of agricultural science has led to the emergence of a new method of plant protection, it is based on improving the immune potential of plants using elicitors, but not on the destruction of pathogens using pesticides. We have studied the effect of disease resistance inducers based on chitosan, organic acids and other substances with elicitor activity, being part of (nano) chips of different composition (matrix carrier - modified natural minerals, activated carbons, nanotubes, graphene, etc..) for pre-sowing seed treatment and for foliar fertilizing. We have studied their influence on growth, development, the incidence of rape plants, the quantity and quality of their crop. We have also determined the efficiency of (nano) chips depending upon their nature and carrier matrix composition.
\end{abstract}

Keywords: elicitors; (nano) chips; pre-sowing seed treatment; growth; development; the incidence of rape plants; the quantity and quality of their crop

\section{INTRODUCTION}

The present level of development of science has led to the emergence of a new method of plant protection, which is based on enhancing the immune capacity of the plant, rather than on the destruction of pathogens, as is the case with pesticides. Substances that induce protective responses in plants are called elicitors (inducers of disease resistance). The first biogenic elicitor was obtained in 1968, since then their number has been annually growing. 
Biogenic elicitors are usually used in very small quantities. Plants are "vaccinated" against the disease, which results in their increased disease resistance. Such preparations are made both abroad and in Russia, they are produced on the basis of bacterial cultures - «Agat-25K», «Fitosporin», «Ekstrasol», «Alirin», «Gamair»; some are based on chitosan - «Hitozar», «Narcissus», «Fitohit», «Agrokhim», «Ekogel»; and some are based on organic acids «Immunotscitofit», «Obereg», «Novosil» (Silk), «Zircon», «Succinic Acid» et al. [1].

The aim of our studies is to investigate the effect of different composition of environmentally friendly (nano) chips based on multi-component polyfunctional (nano) systems, including high-sorption-capacity carrier - matrices of different nature (water-soluble derivatives of natural polymers, natural minerals, carbonaceous sorbents, biogenic elicitors inducers of natural disease resistance (based on chitosan, organic acids and bacterial cultures), as well as the effect of other means of plant protection, their growth and development regulation, used for pre -sowing seed treatment and for the processing of plants during their vegetation with the help of nanotechnology, on the growth, development, yield and quality of rapeseed.

\section{METHODOLOGY}

Development and obtainment of new sorption - capacity (nano) chips for pre-sowing treatment, based on carbon-containing (nano) materials (carbon nanotubes, graphene, activated carbons), silicon dioxide, water soluble polymer and mineral derivatives, as well as the other sorbents together with different plant protection means of biogenic nature, pesticides with sharply reduced application norms (to model conditions in the case of infected backgrounds) are established according to the patent [2].

The field trial was conducted using the common for the Central Chernozem region rape crop cultivation technology [3]. In the trial variants, where we used for seed treatment environmentally friendly (nano) chips, with the elicitors introduced into their composition, we conducted crop spraying with biopesticides in the phases of 4-6 leaves and budding flowering. In all the field trials phenological and phytosanitary surveillance and surveys were carried out according to the generally accepted methods, and the recommendations developed. To protect rape crop from weeds and pests it was treated with herbicides and insecticides during the vegetation period.

Carbon nanomaterial (CNM) "Taunit" represents the one-dimensional nanoscale threadlike formations of polycrystalline graphite in the friableform, resembling powder of black color. CNM granules of micrometer dimensions have the structure of tangled bundles of multi-tubes (MWNT) (Figure 1) [4,5]. We have obtained some new types of CNM "Taunit" using various catalysts and production modes: carbon nanotubes "Taunit - M" and "TaunitMD" having the improved morphological and physico-mechanical properties (Figure 2) [4,5]. The optimal heat treatment of the substances, that preceded catalyst and its composition, provides a few-layered CNM with small diameter variation. Table 1 presents data on various CNM.

Active carbons obtained by recycling annually renewable plant wastes (the straw of various oilseed brassica crops), represent a black powder [6-11]. Powdered activated carbons derived from rape, winter cress, mustard and radish straw according to the developed method (Tables 2, 3) (the product yield level is from 5,7\% to 17,9\%) have the following characteristics: $\mathrm{A}^{\mathrm{c}}-16,5 \%$ wt. to $26,2 \%$ wt ; $\Delta$ - from $60,9 \mathrm{~g} / \mathrm{dm}^{3}$ and $140 \mathrm{~g} / \mathrm{dm}^{3}$; a total pore volume $\mathrm{V} \Sigma$ - from 2,28 to $4,14 \mathrm{~cm}^{3} / \mathrm{g}$; limiting amount of sorption space $\mathrm{W}_{\mathrm{s}}-0,20 \mathrm{~cm}^{3}$ 
/ $\mathrm{g}$ to $0,69 \mathrm{~cm}^{3} / \mathrm{g}$; they have an adsorption ability for iodine from $31,0 \%$ to $62,0 \%$, for methylene blue - from $64,0 \mathrm{mg} / \mathrm{g}$ to $87,0 \mathrm{mg} / \mathrm{g}$. Electron micrographs of powdered activated carbon from straw rape, winter cress and mustard are shown in Figure 3.

Thus, well developed total porosity and relatively vast sorption space allow to effectivelyuse the resulting adsorption RAC for those technologies where powdered activated carbons are used.

Table 1. General characteristics of the series of carbon nanomaterials CNM: "Taunit", "Taunit-M", "Taunit-MD".

\begin{tabular}{|c|c|c|c|}
\hline Parameters & "Taunit" & "Taunit-M" & "Taunit-MD" \\
\hline Externaldiameter, nм & $20 \div 70$ & $30-80$ & $8-15$ \\
\hline Innerdiameter, nм & $5 \div 10$ & $10-20$ & $4-8$ \\
\hline Length, $\mu \mathrm{M}$ & 2 and more & 2 and more & 2 and more \\
\hline $\begin{array}{r}\text { Total admixtures, \% } \\
\text { (after purification) }\end{array}$ & $\begin{array}{l}\text { Up to } 5 \\
\text { (up to } 1 \text { ) }\end{array}$ & $\begin{array}{l}\text { Up to } 5 \\
\text { (up to } 1 \text { ) }\end{array}$ & $\begin{array}{l}\text { Up to } 5 \\
\text { (up to } 1 \text { ) }\end{array}$ \\
\hline Apparentdensity, $\mathrm{g} / \mathrm{cm}^{3}$ & $0,4 \div 0,6$ & $0,03-0,05$ & $0,03-0,05$ \\
\hline Specific geometric surface area, $\mathrm{m}^{2} / \mathrm{g}$ & $\begin{array}{l}120 \div 130 \text { and } \\
\text { more }\end{array}$ & $180-120$ & $\begin{array}{c}\text { 300-320 and } \\
\text { more }\end{array}$ \\
\hline Thermostability, ${ }^{\circ} \mathrm{C}$ & to 600 & to 600 & to 600 \\
\hline
\end{tabular}

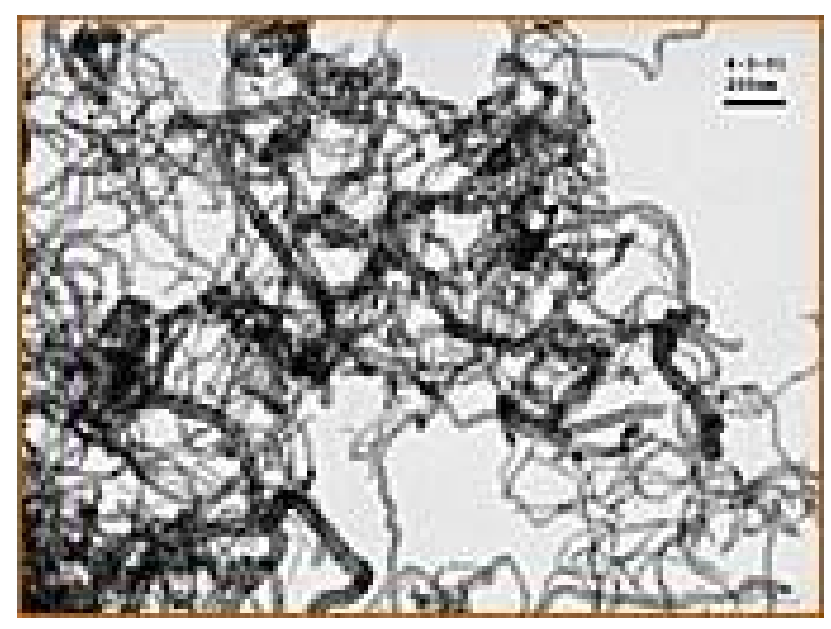

Fig. 1. Electron micrographs based on material "Taunit" 

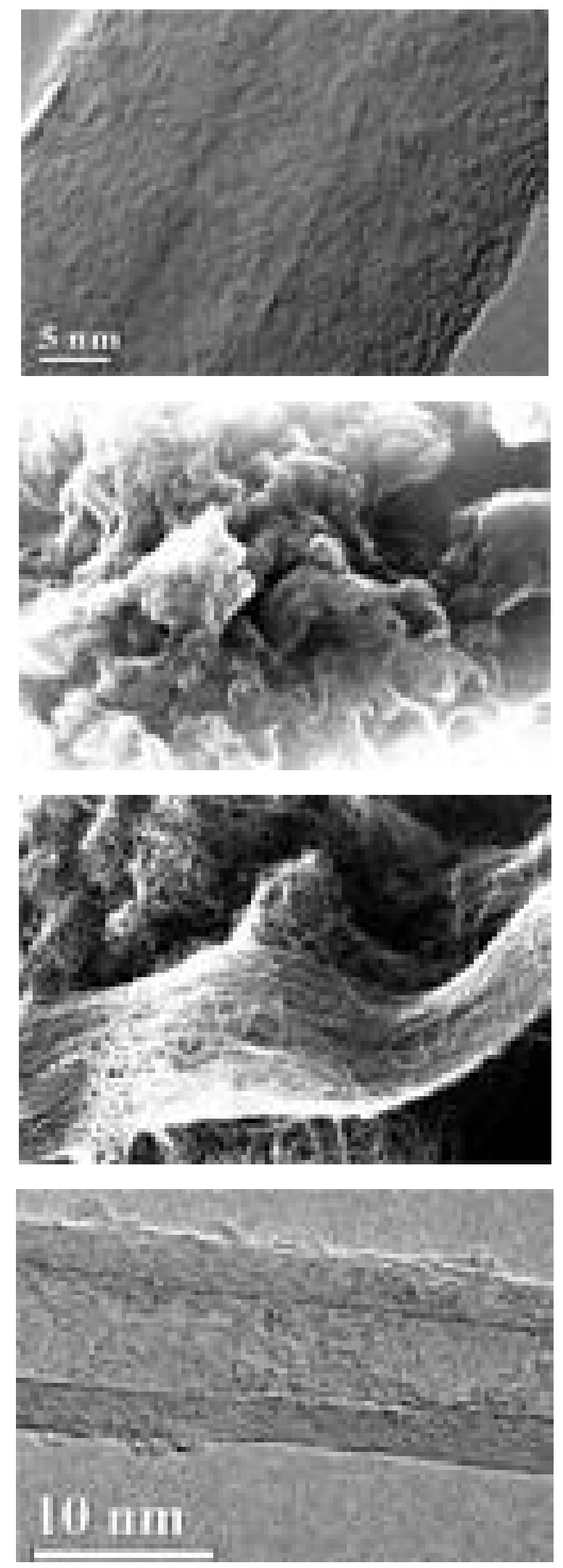

Fig. 2. Electron micrographs of the materials basid on "Taunit-M", "Taunit-MD" with different resolution. 
Table 2. General characteristics of the RAC series of active carbons obtained from the straw of oilseed brassica crops: "RAC-rape", "RAC- winter cress", "RAC-mustard", "RAC- false flax ", "RAUradish".

\begin{tabular}{|c|c|c|c|c|c|c|c|c|c|}
\hline \multirow{2}{*}{ 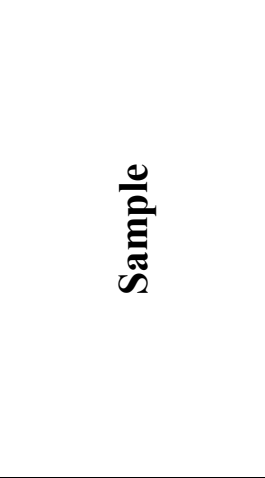 } & \multirow{2}{*}{$\overbrace{}^{\infty}$} & \multirow{2}{*}{$\sum^{\sum_{0}^{n}}$} & \multirow{2}{*}{$\frac{\partial^{0}}{e_{0}^{0}}$} & \multirow{2}{*}{$\sum_{\substack{0 \\
j}}^{\infty}$} & \multirow{2}{*}{$\frac{\partial}{\tilde{\Xi}}$} & \multicolumn{2}{|c|}{ 咅总弟 } & \multirow{2}{*}{ 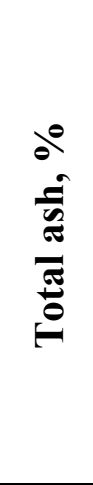 } & \multirow{2}{*}{ 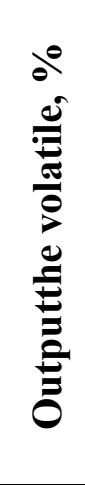 } \\
\hline & & & & & & $\begin{array}{l}0^{0} \\
\stackrel{0}{0} \\
.0 \\
.0\end{array}$ & 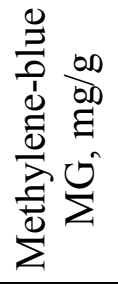 & & \\
\hline 1. Rape & 4,14 & 0,48 & 2,4 & 135 & 10,3 & 39 & 87 & 16,5 & 16,0 \\
\hline 2. Falseflax & 2,43 & 0,69 & 5,7 & 140 & 5,7 & 43 & 82 & 15,6 & 12,6 \\
\hline 3. Radish & 2,55 & 0,20 & 2,2 & 131 & 17,9 & 31 & 69 & 26,2 & 15,3 \\
\hline 4. Wintercress & 2,28 & 0,57 & 1,5 & 135 & 8,1 & 62 & 73 & 22,1 & 12,8 \\
\hline $\begin{array}{c}5 . \\
\text { Whitemustard }\end{array}$ & 4,0 & 0,45 & 2,8 & 60,9 & 11,0 & 50 & 64 & 24,4 & 11,2 \\
\hline $\begin{array}{c}6 . \\
\text { Brownmustard }\end{array}$ & 2,81 & 0,57 & 3,4 & 111 & 7,3 & 56 & 67 & 27,3 & 10,6 \\
\hline
\end{tabular}

Table 3. The micropore volume and micropore size for the isotherms of a series of activated carbons RAC obtained from the straw of oilseed brassica crops: "RAU-rape", "RAU-winter cress", "RAUmustard", "RAU-false flax", "RAU-radish".

\begin{tabular}{|c|c|c|c|c|c|}
\hline \multirow{2}{*}{ Sample } & \multirow{2}{*}{$\begin{array}{c}\text { Micropore } \\
\text { volume, } \\
\mathbf{c m}^{\mathbf{3}} / \mathbf{g}\end{array}$} & $\begin{array}{c}\text { Equivalent pore width, } \\
\mathbf{n m}\end{array}$ & \multirow{2}{*}{$\mathbf{S}_{\text {equ }}, \mathbf{m}^{\mathbf{2}} / \mathbf{g}$} & $\begin{array}{c}\mathbf{E}_{\mathbf{a}}, \\
\text { kilojoule/mole }\end{array}$ \\
\cline { 3 - 4 } & \multicolumn{7}{|c|}{ average } & modal & \\
\hline oil-bearing cabbage plants \\
\hline Rape & 0,161 & 1,58 & 1,42 & 454 & 22,7 \\
\hline Wintercress & 0,124 & 1,53 & 1,38 & 350 & 24,9 \\
\hline Whitemustard & 0,161 & 1,57 & 1,39 & 454 & 23,2 \\
\hline Brownmustard & 0,163 & 1,50 & 1,32 & 459 & 26,2 \\
\hline Radish & 0,116 & 1,62 & 1,51 & 328 & 21,0 \\
\hline
\end{tabular}



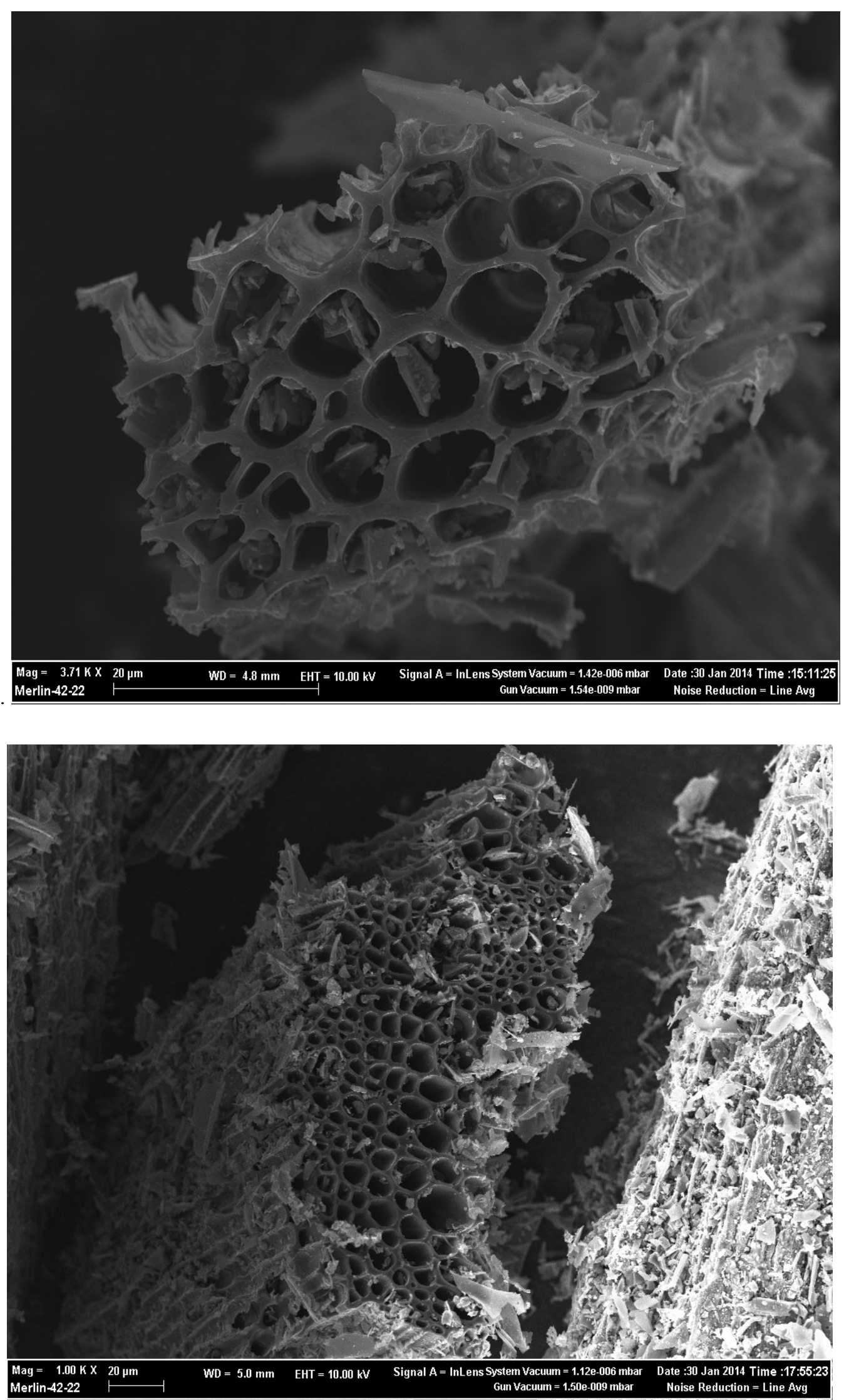


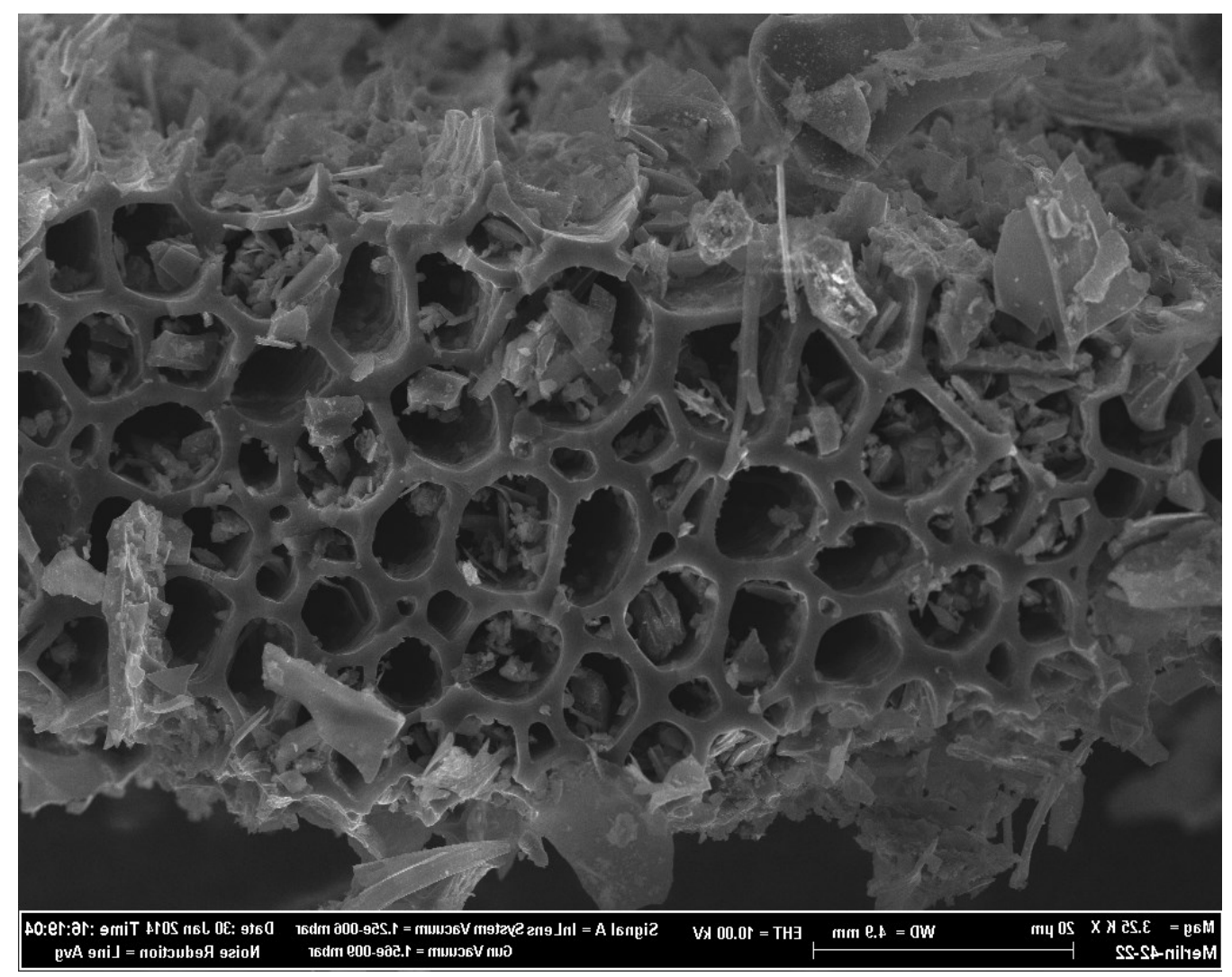

Figure 3. Electron micrographs of powdered activated carbon, obtained from rape straw -1, mustard straw -2 , winter cress straw -3 .

\section{RESULTS AND DISCUSSION}

Using new nanomaterials in the agricultural sector to solve various problems of agricultural production is one of the foreground goals of today. The studies conducted at Arkansas University of Nanotechnology Center at Little Rock, also at Tambov State University named after G.R. Derzhavin (Training Innovation Center for Nanotechnologies and Nanomaterials) together with the Tambov State Technical University (Co Ltd "NanoTehTsentr") and others, have shown that putting tomato seeds, tobacco, sainfoin, rape, wheat and some other crops into a nutrient solution containing carbon nanotubes leads to stimulation of their germination, plant growth and development improvement, biomass accumulation increase and also to higher yields due to the penetration of nanotubes through the seed coats into various plant organs [12-19]. We have also managed to identify the effects, observed during our experiments, where we used for pre-sowing seed treatment new nanoporous (nano) chips based on carbonaceous sorbents with the different plant protection products of biogenic nature included into their composition.

The conducted laboratory studies have shown that the treatment of rape seeds before sowing using nanoporous carbonaceous materials ("Taunit", "Taunit-M," "Taunit-MD", graphite and activated carbons obtained from the straw of different crops (table 1,2,3;pic.1,2,3) with the micronutrient malnutrition included into their composition, as well as the drugs with fungicidal, bactericidal and eliciting properties, tended to sharply accelerate the process of seed germination (the number of "arisen" seeds on the first germination day, 
depending on the composition, was 20,2-32,5\% (while in the control variant (where the seeds have not been treated) it was - 19,8\%), on the second day it was 90,5-93,0\%. It also facilitated the increase of vigor, laboratory germination, seedling length and fresh weight accumulation, which can be probably explained by the possibility of the idea that physiologically active polyfunctional (nano) chips based on nanotubes penetrate inside the seed and then into the cells and tissues of seedlings and plants. The conducted field trials revealed an obvious differentiation between the various trial variants depending on the composition of multifunctional complex (nano) chips applied to the surface of rape seeds in the process of pre-treatment using (nano) technology and in the process of crop spraying with biopesticide having an eliciting activity. Besides, when using (nano) chips with nanotubes applied as matrix carriers, the yield increase was $14,4 \%-74,0 \%$, depending on their structure; with graphene it was $-22,0 \%$; with RAU active carbons obtained by rape and camelina straw processing, and with Agrosorb, it was - 16,1\%; 55,8\%; 49,2\%, respectively; with mineral derivatives $-5,7 \%-14,8 \%$, depending on their composition; with water-soluble polymers it amounted to $8,0 \%-12,0 \%$, depending on their nature.

\section{CONCLUSION}

Thus, when applying a nanotechnology while processing the surfaces of seeds and plants, nano-sized structures are being formed, providing a high efficiency of mineral nutrition process, plant protection and development, and also contributing to the following yield increase. In connection with the stated above, sorption-capable nanoporous materials can be effectively used to transfer the preparations with elicitor activity, to transfer the necessary plant protection products and their trace elements to accelerate seed germination process, to improve plant growth and development.

The work has been performed as a part of R\&D task to "Develop an environmentally safe (nano) technology of pre-sowingseed treatment of brassica crops using (nano) chip-based biopesticides"; "Create a new oilseed varieties of cabbage crops, combining high productivity with resistance to major pathogens, pests, abiotic stressors, technological in production" and the assignment № 16.711.2014/ K to perform a research under the project of the state task to the educational organizations and higher education scientific organizations under RF Ministry of Education and Science.

\section{Благодарности.}

Коллектив авторов выражает благодарность фондам за поддержск проводимых исследований и переводчику Е. Симциовой за высокий профессионализм в работе.

The work is performed as part of the task 04.07.05.01. "To study the effect of (nano) chip-based biopesticides on plant growth, development, yield and quality for the development of environmentally safe (nano) technology presowing treatment of seeds of oilseed brassica crops" in within the framework№ 16.711 .2014 / K to perform the research within the project of the state task for the educational organizations of higher education and scientific organizations attached to the Education and Science Ministry. 


\section{References}

[1] List of pesticides and agricultural chemicals approved for application on the territory of the Russian Federation. M.-2013. p.935.

[2] Ruban, N. Voropaeva, O.L. Figovsky, et.al., Patent USA, 2012, №12459518.

[3] V.V. Karpachev. Spring rape. Lipetsk. 2008, 236 p.

[4] Tkachev A.G., Dyachkova T.P. Methods for functionalization and modification of carbon nanotubes .// M. Publ. House "Spectr", 2013, 152 p.

[5] Y.I. Golovin, Stolyarov R.A., Tkachev A.G.A method for producing bulk nanostructured material // Patent 2475445 RF, 2013.

[6] Mukhin V.M., V.N.Klushin. The production and use of carbon adsorbents. MM: RCTU of D.I. Mendeleev, 2012, 305 p.

[7] Mukhin V.M., Voropaeva N.L., V.V. Karpachev, Rape straw as raw material to produce activated carbons // Feed-production 1 (2014) 41-43.

[8] RF Patent 2527221. Mukhin V.M., Karpachev V.V., Kharlamov S.A., Voropaeva N.L. et al. A method for producing activated carbon from vegetable waste. Priority on 09/04/13. Registeredin the State Register of Inventions of Russia 07.07.14.

[9] V. Mukhin, N. Voropaeva, V. Karpachev, O. Figovsky. Plant residues of various agricultural crops as renewable raw material for obtaining activated carbon, (ISSN1565-1533) 16(2) (2014) 186-189.

[10] N.L. Voropaeva, V.M. Mukhin, Gorshkova E.K, Belonozhkina T.G., O.L. Figovsky, V.V. Karpachev. Environmentally safe polymerous (nano) chips with activated carbon added for agriculture "environmentalization», Abstracts of Communication «The International Conference dedicated to the $55^{\text {th }}$ anniversary from the foundation of the Institute of the Academy of Sciences of Moldova», Moldova, Chisinau. 2014, p. 188.

[11] V. Mukhin, T. Lupascu, N. Voropaeva, Y. Spiridonov, N. Bogdanovich, Vasiliy Gurjanov, Industrial and Ecological Chemistry 9(1) (2014) 1-4.

[12] AlekseevaA. Carbon nanotubes in biology. Perspective Technologies (in Russian), 2009. - T. 16, C. 5-7.

[13] Quotes taken from: http://www.agroxxi.ru/arhiv-novostei/nanotehnologi-perspektiva-idlja-selskogo-hozjaistva.html.

[14] Quotes taken from: www.abercade.ru/research/industrynews/2678.html

[15] Quotes taken from html //www.nanotc.ru>index.php?option=com_content\&task=view...

[16] Smirnova E., Gusev A., Sheina O., Tkachev A., Lazareva E., Frontiers of Chemical Science and Engineering 1 (2012) 15-19.

[17] Gusev, O. Akimova, O. Zakhrova, et.al., Advanced materials research 880 (2014) 212218.

[18] Smimova E.A., Gusev A.A., Ser. Acta Naturae 3 (2011) 106-113.

[19] Tripathi S., Sonkar S. K., Sarkar S. Nanoscale 3C (2011) 1176-1178. 